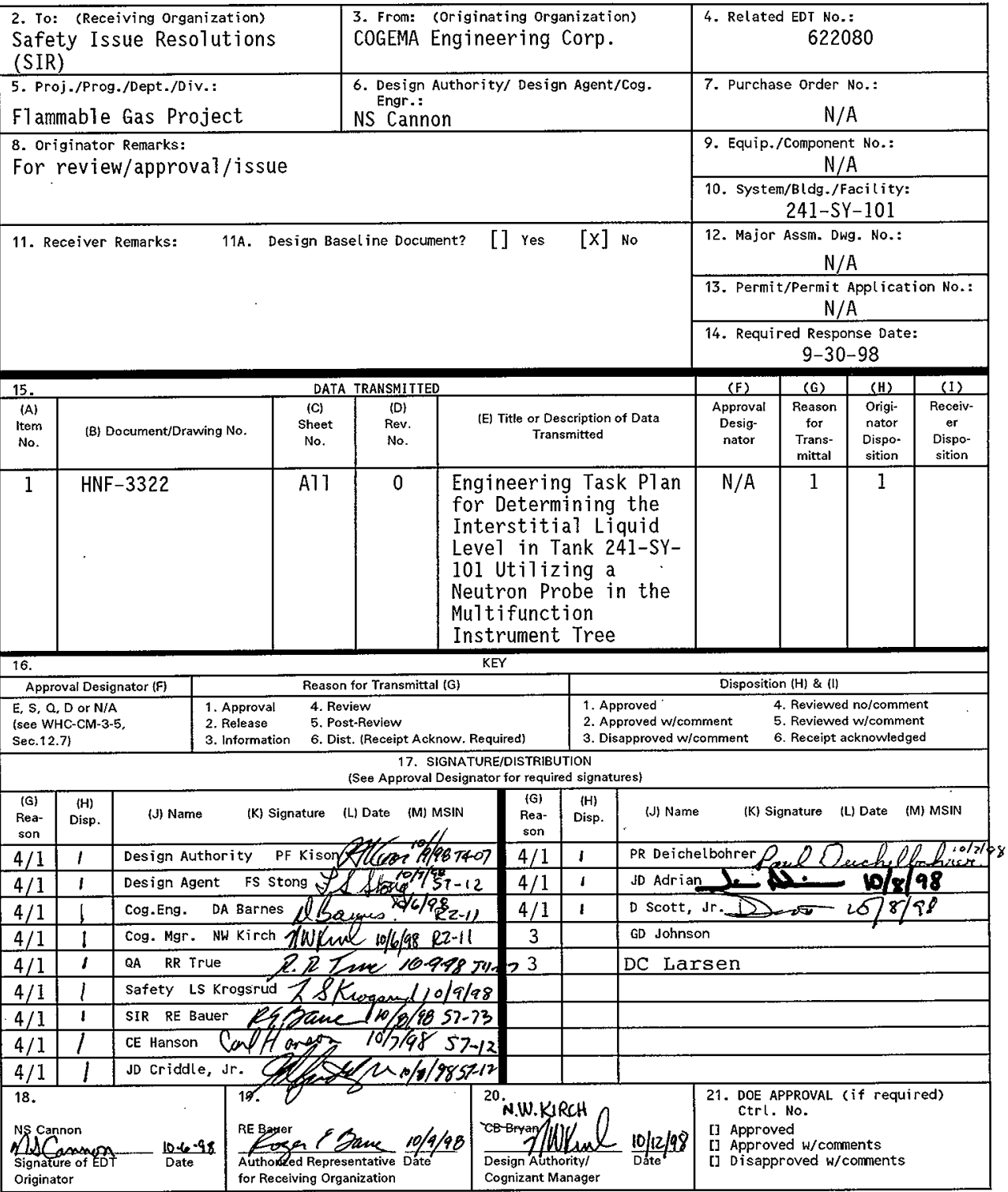




\title{
Engineering Task Plan for Determining the Interstitial Liquid Level in Tank 241-SY-101 Utilizing a Neutron Probe in the Multifunction Instrument Tree
}

\author{
N. S. Cannon \\ COGEMA Engineering Corporation, Richland, WA 99352 \\ U.S. Department of Energy Contract DE-AC06-96RL13200 \\ EDT/ECN: $\quad 140119$ \\ UC: 2070 \\ Org Code: 08E00 \\ Charge Code: 106033BA10 \\ B\&R Code: EW3120074 \\ Total Pages: 20
}

Key Words: engineering task plan (ETP), 241-SY-101, interstitial 1iquid level (ILL), neutron, gamma, probe, mult ifunction instrument tree (MIT), flammable gas, inventory, hazard

Abstract: This plan outlines the steps to be taken to modify existing neutron/gamma probe designs to allow insertion of these probes into the multifunction instrument trees (MITs) at tank 241-SY-101. The objective is to locate and track this tank's Interstitial Liquid Level (ILL). This plan provides scope, schedule, and cost estimates to achieve this objective, and assigns individual organizational responsibitities to carry out this task.

TRADEMARK DISCLAIMER. Reference herein to any specific commercial product, process, or service by trade name, trademark, manufacturer, or otherwise, does not necessarily constitute or imply its endorsement, recommendation, or favoring by the United states Government or any agency thereof or its contractors or subcontractors.

Printed in the United States of America. To obtain copies of this document, contact: Document Control Services, P.0. Box 950, Mailstop H6-08, Richland WA 99352, Phone (509) 372-2420; Fax (509) 376-4989.
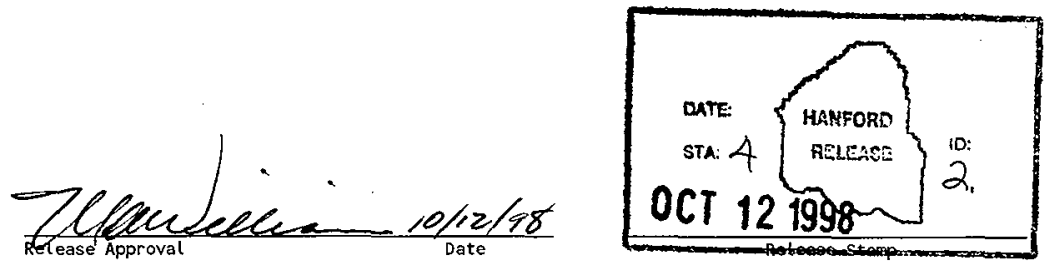

Approved for Public Release 
HNF.3322 Rev. 0

ENGINEERING TASK PLAN FOR DETERMINING THE INTERSTITIAL LIQUID LEVEL IN TANK 241-SY-101 UTILIZING A NEUTRON PROBE IN THE MULTIFUNCTION INSTRUMENT TREE

HNF-3322

Revision 0

N. S. Cannon

COGEMA Engineering Corporation

October 12, 1998 


\section{TABLE OF CONTENTS}

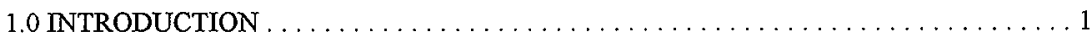

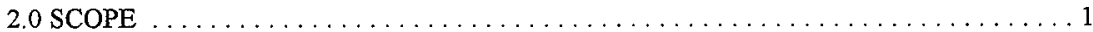

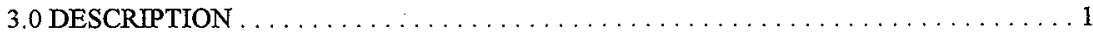

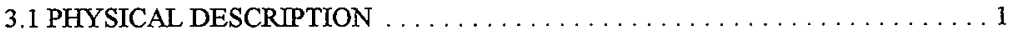

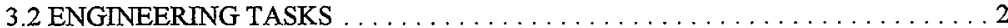

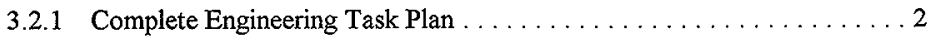

3.2 .2 Probe Procurement . . . . . . . . . . . . . . . . . . . . 2

3.2 .3 Modifications ................................ 3

3.2.4 Perform Pre-Operational Testing ...................... 3

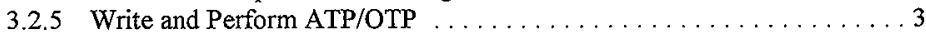

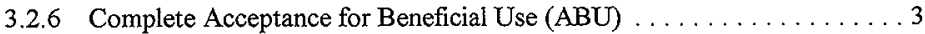

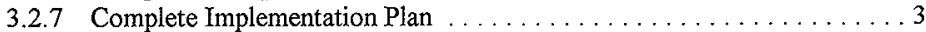

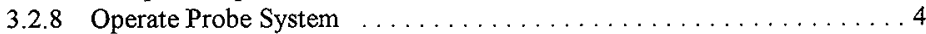

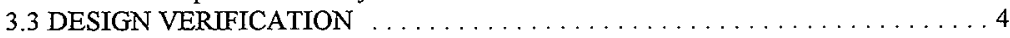

3.4 SOFTWARE DEVELOPMENT TASKS $\ldots \ldots \ldots \ldots \ldots \ldots \ldots \ldots \ldots$

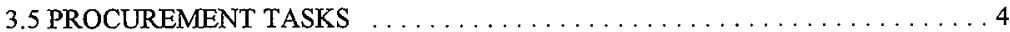

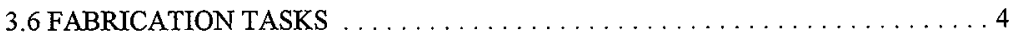

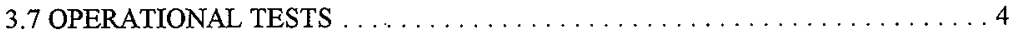

3.8 ACCEPTANCE FOR BENEFICIAL USE $\ldots \ldots \ldots \ldots \ldots \ldots \ldots \ldots \ldots \ldots$

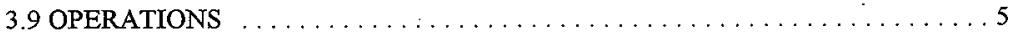

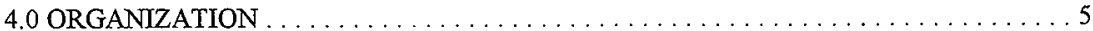

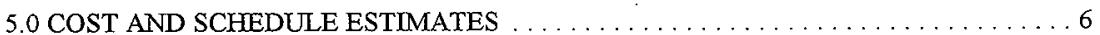

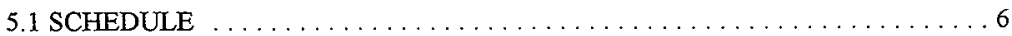

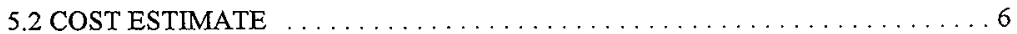

6.0 CONFIGURATION MANAGEMENT $\ldots \ldots \ldots \ldots \ldots \ldots \ldots \ldots \ldots \ldots \ldots \ldots \ldots \ldots \ldots$

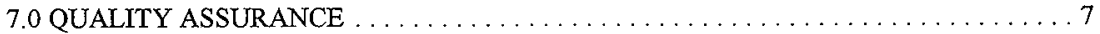

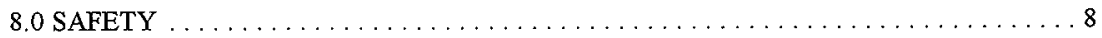

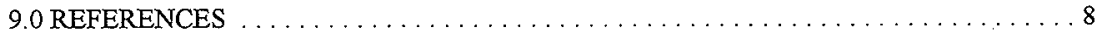




\section{TABLE OF CONTENTS (Cont.)}

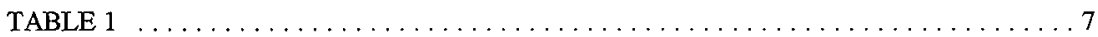

ATTACHMENT A: Acceptance for Beneficial Use $(\mathrm{ABU}) \ldots \ldots \ldots \ldots \ldots \ldots \ldots$ A-1

ATTACHMENT B: Neutron/Gamma Probe Schedule . . . . . . . . . . . . . . . B-1 


\section{ENGINEERING TASK PLAN FOR DETERMINING THE INTERSTITIAL LIQUID LEVEL IN TANK 241-SY-101 UTILIZING A NEUTRON PROBE IN THE MULTIFUNCTION INSTRUMENT TREE}

\subsection{INTRODUCTION}

There have not been any repetitions of the spontaneous (and episodic), large volume gas release events that occurred in Tank 241-SY-101 prior to the installation of the mixer pump since its operation was initiated. However, the crust surface level of Tank 241-SY-101 has been slowly rising (as determined by level-gauge measurements). There is concern that there may be a pressurized slurry beneath the surface crust or increased gas retention within the tank contents causing a volume increase. The concern occurs because the rising waste level might be an indication of a decreasing margin of safety for the 241-SY-101 tank.

To investigate options for providing information that could assist in evaluating this concern, the Safety Issue Resolution (SIR) organization recommended performance of a feasibility study for utilizing a neutron probe to visualize and measure certain aspects of the material beneath the surface crust, and more specifically, to determine the location of the interstitial liquid level (ILL). This study has been completed (Stong, 1998), and it is the purpose of this Engineering Task Plan (ETP) to implement one of the feasible options recommended by Stong (Option D of Appendix B).

\subsection{SCOPE}

The object of the work defined in this document is to provide a neutron/gamma probe system for implementation in the 241-SY-101 multifunction instrument trees (MITs), and to operate that system for the purpose of measuring and tracking the location of the ILL.

\subsection{DESCRIPTION}

\subsection{PHYSICAL DESCRIPTION}

The objective of this task is to redesign and modify an existing neutron probe system so that probes can be lowered down the central validation tubes of the two MITs at Tank 241-SY-101 for the purpose of measuring and tracking the $\mathrm{IL}$ in this tank. This task encompasses the redesign and fabrication of a neutron probe and a gamma probe to interface with the existing liquid observation well (LOW) vans, which provide the necessary instrumentation, 
and to provide probe geometries that allow each probe to be lowered into either of the two MITs. The task also includes completing the necessary testing, documentation, and reviews (as described in Section 3.2) for operation of the probe system at this tank through FY99, and analyzing the data results obtained.

A description of the location of the two MTs of Tank 241-SY-101 is given in Drawing $\mathrm{H}-14-010531$ (Sheet 1), an overview of the MITs is illustrated in Drawing H-2-85141 (Sheet 1), and the dimensions of the MIT validation tube are given in Drawing H-2-85145 (Sheet 3). From this last drawing, the inside diameter (ID) of the MTT validation tube (into which the probes are to be inserted) is shown as 1.984 in $(5.04 \mathrm{~cm})$, which has obvious relevance to the maximum allowable probe outside diameter (OD).

The LOW equipment required for this task is operated in accordance with the tank farm operating procedure TO-040-333 (1998). All probe and supporting system equipment operated at the 241-SY-101 tank must comply with this procedure.

\subsection{ENGINEERING TASKS}

The engineering tasks to be performed for this program are described in the following, and individual contractors assigned for each task are indicated in parentheses at the end of each section. These contractors include COGEMA Engineering Corporation (COGEMA Engineering), Lockheed Martin Hanford Corporation (LMHC), and Numatec Hanford Corporation (NHC).

\subsubsection{Complete Engineering Task Plan}

The ETP is a required tool for managing the neutron probe program to determine and track the KLL in Tank 241-SY-101; it is provided by this document. (COGEMA Engineering, LMHC)

\subsubsection{Probe Procurement}

In order to adapt the existing neutron probe system to operate in the MITs at the 241-SY101 tank, it is necessary to modify the probe hardware. Design changes will be made that include a reduction of the probe diameters. The new design calls for a separate neutron probe and gamma probe, both of which must be procured. Procurement of the neutron probe will require a special effort, as it is likely that the probe, detector, and source will be obtained from separate vendors. The supplier of the neutron and gamma probes will be required to provide Certified Vendor Information (CVI) drawings of these devices. (COGEMA Engineering, LMHC) 


\subsubsection{Modifications}

A number of hardware and software modifications will be required to prepare the neutron probe system to operate in the 241-SY-101 MITs. Engineering Change Notices (ECNs) and $\mathrm{H}-2 / \mathrm{H}-14$ drawings (or drawing modifications) will be provided as required. Also, because the new probe design requires a change in the neutron source (to a higher dose rate), it may be necessary to provide an ALARA Management Worksheet. Items that require (or may require) modification include:

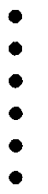

$$
\begin{aligned}
& \text { software } \\
& \text { plug gage } \\
& \text { van offset fixture } \\
& \text { probe holder } \\
& \text { neutron source storage cask. } \\
& \text { ALARA Management Worksheet }
\end{aligned}
$$

(LMHC)

(NHC, Crafts)

(NHC, Crafts)

(NHC, Crafts)

(NHC, Crafts)

(LMHC)

\subsubsection{Perform Pre-Operational Testing}

The procurement specifications for the neutron and gamma probes will require the vendor to perform certain limited operational tests before shipping the probes. However, the vendor facility lacks some of the testing capability that is available on the Hanford site. Thus, in cooperation with the vendor, a series of "pre-operational" tests will be performed at Hanford to verify basic functionality of the equipment, prior to formal acceptance testing. This effort will require a test plan and test procedures. (COGEMA Engineering, Crafts)

\subsubsection{Write and Perform ATP/OTP}

A combined Acceptance Test Procedure/Operations Test Procedure (ATP/OTP) will be written and performed to verify specification compliance and compatibility of the new probes and software with the existing LOW system. The resulting data will be evaluated and an operations test report (OTR) will be issued. (COGEMA Engineering, LMHC)

\subsubsection{Complete Acceptance for Beneficial Use (ABU)}

An acceptance for beneficial use (ABU) process will be completed. The actual ABU checklist and forms for this task are shown in Attachment A. (COGEMA Engineering, LMHC)

\subsubsection{Complete Implementation Plan}

Once the ATP/OTP and ABU have been completed, an implementation plan will be completed to allow for continued operation of the neutron probe system at the MITs of Tank 241-SY-101. (COGEMA Engineering) 


\subsubsection{Operate Probe System}

The neutron probe system will be operated at Tank 241-SY-101 through the end of FY99, measuring and tracking the ILL. (COGEMA Engineering, LMHC, Crafts)

\subsection{DESIGN VERIFICATION}

The current LOW equipment design has been approved for use in LOWs (including those installed in flammable gas tanks), which is a non-intrusive application. Any additional ECNs required for this effort will be reviewed through the informal design review process per HNF $1997 \mathrm{a}$.

\subsection{SOFTWARE DEVELOPMENT TASKS}

Modification of existing LOW software may be required to obtain and properly analyze data obtained from the 241-SY-101 MITs. These modifications will be performed by LMHC, as required.

\subsection{PROCUREMENT TASKS}

Procurement activities will be handled by LMHC; items will be procured though LMHC utilizing COGEMA Engineering personnel as the procurement coordinator. The safety classification of the components will be determined by the Design Authority with input from COGEMA Engineering personnel. It is noted that the current probe system is not safety class or safety significant; its GS safety class rating is based on the fact that the probe system and associated electronics are confined to the LOW and are not intrusive in the tank. The probe system serves no safety function, and does not interact with (or affect) other safety equipment at the tank.

\subsection{FABRICATION TASKS}

It is expected that most of the fabrication associated with this program will be performed by the vendor supplying the modified neutron and gamma probes. However, any on-site fabrication activity (if necessary) for this task plan will be performed by DynCorp Fab Shops.

\subsection{OPERATIONAL TESTS}

An ATP/OTP will be performed to formally assess the functionality of the neutron probe system and its compatibility with the LOW trucks. System calibration(s) will be included in this task. The results of this testing will be documented in an OTR. 


\subsection{ACCEPTANCE FOR BENEFICIAL USE}

The ABU process checklist/forms that will be used for this task are shown in Attachment A.

\subsection{OPERATIONS}

All installation and system operational activities associated with the ETP will be performed by LMHC (or their designates).

\subsection{ORGANIZATION}

Responsibilities are assigned to various companies and organizations as identified in the following paragraphs.

DESH will provide the overall project direction and funding.

- Cost Account Manager (CAM): R. E. Bauer

COGEMA Engineering will provide project management and engineering services to perform any required design, design documentation, and engineering support during fabrication/installation, testing, initial deployment, and task management.

- COGEMA Engineering Project Manager:

C. E. Hanson

- Responsible Manager:

J. D. Criddle

- Responsible Engineer:

N. S. Cannon

- Engineer:

F. S. Stong

LMHC will provide support to implement the new system at the 241-SY-101 tank, and to provide continued operational support through FY99.

- LMHC Operations Manager:

C. B. Bryan

- Cognizant Manager:

N. W. Kirch

- Cognizant Engineer:

D. A. Barnes

- Design Authority:

P. F. Kison 

- Responsible Manager
D. Scott, Jr.
- $\quad$ Responsible Manager
J. D. Adrian
- Quality Assurance Engineer
R. R. True
- Safety Engineer
L. S. Krogsrud

NHC will provide support for making needed system modifications, including modifying the plug gage, the offset fixture, the probe holder, and the neutron source storage cask.

- Responsible Engineer:

P. R. Deihelbohrer

\subsection{COST AND SCHEDULE ESTIMATES}

Cost and schedule for both engineering, fabrication, and testing are dependent on many variables. As such, these are not "fixed price" or "fixed schedule" estimates. COGEMA Engineering will closely manage the task and report any cost or schedule issues to the appropriate management.

\subsection{SCHEDULE}

The schedule estimate prepared by COGEMA is given in Attachment $B$. Key dates in the schedule are completion of the Acceptance for Beneficial Use (ABU) by December 29, 1998, the initiation of $I L L$ measurement/analysis on January 20, 1999, with a continuation of the tracking of the ILL through September 30, 1999.

\subsection{COST ESTIMATE}

A simplified cost estimate is given in the following table (Table 1) in terms of manhours unless otherwise specified. This estimate does not include any costs incurred by this project prior to August 24, 1998.

\subsection{CONFIGURATION MANAGEMENT}

The current baseline configuration of the LOW van system will not change for this task; new probes are being designed and fabricated to interface with the existing LOW system. All new vendor supplied drawings shall be added to the existing CVI file (50014). New parts fabricated "in-house" for this program will have required drawings released per WHC 1996, HNF 1997b, and HNF 1997c. ECNs will be generated against these new design drawings to reflect the 
additional modifications required to support this task. These ECNs will be prepared in accordance with WHC 1996 and HNF 1997d.

\subsection{QUALITY ASSURANCE}

All documentation (ECNs, etc.) associated with this task shall be assigned approval

\begin{tabular}{|c|c|c|c|c|c|c|}
\hline \multicolumn{7}{|c|}{ TABLE 1: TASK IMPLEMENTATION COST ESTIMATE } \\
\hline TASK & COGEMA & LMHC & $\begin{array}{c}\text { OPS } \\
\text { Mangement }\end{array}$ & Operations & CRAFTS & NHC \\
\hline $\begin{array}{l}\text { Engineering Task } \\
\text { Plan }\end{array}$ & 200 & 40 & & & & \\
\hline Probe Procurement & 392 & 96 & & & & \\
\hline Probe Hardware & & $\$ 30 \mathrm{~K}^{*}$ & & & & \\
\hline System Mods & 8 & 64 & & & & \\
\hline Well Logging & & & 16 & 24 & 16 & 56 \\
\hline Offset Fixture Mod & 8 & & . & & 8 & 56 \\
\hline Probe Holder Mod & & & & & 24 & 40 \\
\hline Source Cask Mod & & & & & 24 & 40 \\
\hline Pre-Op. Testing & 136 & & 32 & 32 & & \\
\hline ATP/OTP & 224 & 88 & 8 & 40 & & \\
\hline $\mathrm{ABU}$ & 32 & 8 & . & & & \\
\hline Implementation Plan & 120 & & & & & \\
\hline Operational Phase & 792 & 1728 & & 1248 & & \\
\hline TOTAL (hrs) & 1912 & 2024 & 56 & 1344 & 72 & 192 \\
\hline FY98 Total (hrs) & 688 & 160 & 16 & 24 & 16 & 112 \\
\hline FY99 Total (hrs) & 1224 & 1864 & 40 & 1320 & 56 & 80 \\
\hline
\end{tabular}

" Expected purchase order cost for probe components 
designators by the cognizant engineer with concurrence from the cognizant manager. The approval designator shall be determined from Table 1 of HNF 1997e. Those documents given an approval designator " $Q$ " will be reviewed and approved by Quality Assurance per WHC 1991. A final verification/walkdown of the probe system shall be performed in accordance with HNF $1997 \mathrm{f}$ prior to completion of the ABU. The ATP/OTP and OTR for the probe system will be conducted in accordance with HNF $1997 \mathrm{~g}$.

\subsection{SAFETY}

All documentation (ECNs, etc.) associated with this task shall be assigned approval designators by the cognizant engineer with concurrence from the cognizant manager. The approval designator shall be determined from Table 1 of HNF 1997e. Those documents given an approval designator "S" will be reviewed and approved by Safety.

\subsection{REFERENCES}

HNF, 1997a, HNF-PRO-445, Rev. 0, Project Hanford Policy and Procedure System Design Verification Requirements, Fluor Daniel Hanford, Inc., Richland, Washington.

HNF, 1997b, HNF-PRO-244, Rev. 0, Project Hanford Policy and Procedure System Engineering Data Submittal Requirements, Fluor Daniel Hanford, Inc., Richland, Washington.

HNF, 1997c, HNF-PRO-317, Rev. 0, Project Hanford Policy and Procedure System Engineering Release and Approval Requirements, Fluor Daniel Hanford, Inc., Richland, Washington.

HNF, 1997d, HNF-PRO-440, Rev. 0, Project Hanford Policy and Procedure System Engineering Document Change Control Requirements, Fluor Daniel Hanford, Inc., Richland, Washington.

HNF, 1997e, HNF-PRO-233, Rev. 0, Project Hanford Policy and Procedure System Review and Approval of Documents, Fluor Daniel Hanford, Inc., Richland Washington.

HNF, 1997f, HNF-PRO-283, Rev. 0, Project Hanford Policy and Procedure System Control of Inspections, Fluor Daniel Hanford, Inc., Richland, Washington.

HNF, 1997g, HNF-PRO-286, Rev. 0, Project Hanford Policy and Procedure System Test Control, Fluor Daniel Hanford, Inc., Richland, Washington. 
Stong, F. S., 1998, HNF-3041, Determining the Interstitial Level in Tank 241-SY-101 Utilizing a Neutron Probe in the Multifunction Instrument Tree, COGEMA Engineering Corporation, Richland, Washington.

TO-040-33, Rev. A-4, January 7, 1998, Liquid Observation Well (LOW) Surveillance Van Startup and Operation Procedure, Westinghouse Hanford Company, Richland, Washington

WHC, 1996, WHC-IP-0842, TWRS Administration, Volume IV, Section 3.5, Rev. 1, "Engineering Documents," Westinghouse Hanford Company, Richland, Washington. 
ATTACHMENT A: ABU

\begin{tabular}{|c|c|c|c|c|c|}
\hline \multicolumn{6}{|c|}{ ACCEPTANCE FOR BENEFICIAL USE (ABU) } \\
\hline $\begin{array}{l}\text { 3. Document No. } \\
\text { HNF-3322 }\end{array}$ & $\begin{array}{l}\text { 4. Project No. } \\
\text { NA }\end{array}$ & $\begin{array}{l}\text { 5. SSC } \\
\text { Designator } \\
\text { GS }\end{array}$ & $\begin{array}{l}\text { 6.System/BIdg/ } \\
\text { Facility } \\
241-S Y-101\end{array}$ & $\begin{array}{l}\text { 7.Equip/Component } \\
\text { No. }\end{array}$ & $\begin{array}{l}\text { 8. ECN/EDT No. } \\
\text { EDT } 140119\end{array}$ \\
\hline 9. Final ABU ( ) & \multicolumn{2}{|c|}{ Partial ABU ( ) } & \multicolumn{3}{|l|}{ 10. ATP Rerun Required } \\
\hline \multicolumn{6}{|c|}{$\begin{array}{l}\text { 11. Description of Work } \\
\text { Modify Neutron/Gamn } \\
\text { accordance with proc }\end{array}$} \\
\hline \multicolumn{6}{|c|}{$\begin{array}{l}\text { This ABU documents the completion of all activities necessary for the deployment of modified neutron } \\
\text { and gamma probes with the existing LOW vans at Tank } 241-S Y-101 \text { MITs. }\end{array}$} \\
\hline 12. Description of & to be Completed & $\begin{array}{l}\text { 13. Scheduled } \\
\text { Completion Date }\end{array}$ & $\begin{array}{l}\text { 14. Responsibility for } \\
\text { Completion }\end{array}$ & 15. Impact on Operat & is/Safety \\
\hline
\end{tabular}

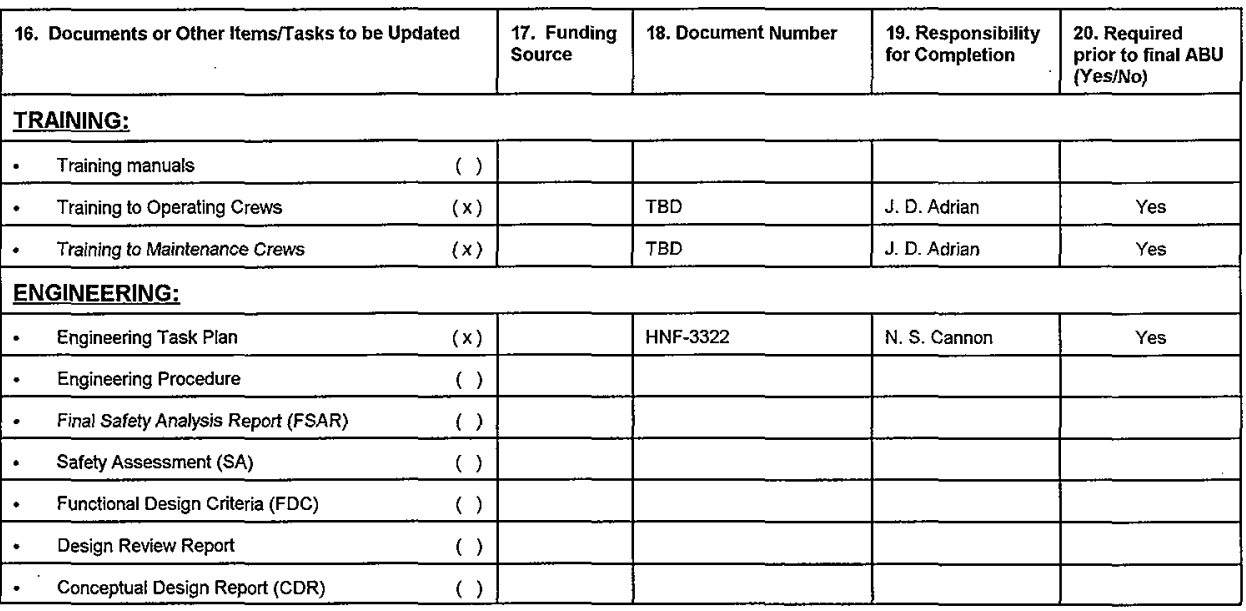


HNF-3322 Rev. 0

\begin{tabular}{|c|c|c|c|c|c|}
\hline • & $\begin{array}{l}\text { Supplemental Design Requirements Document } \\
\text { (SDRD) }\end{array}$ & & & . & \\
\hline \multicolumn{2}{|r|}{ 16. Documents or Other Items/Tasks to be Updated } & $\begin{array}{l}\text { 17. Funding } \\
\text { Source }\end{array}$ & 18. Document Number & $\begin{array}{l}\text { 19. Responsibility } \\
\text { for Completion }\end{array}$ & $\begin{array}{l}\text { 20. Required } \\
\text { prior to final ABU } \\
\text { (Yes/No) }\end{array}$ \\
\hline$\cdot$ & System Design Description (SDD) & & & & \\
\hline$\cdot$ & $\begin{array}{l}\text { Test procedures/specifications } \\
\text { Test Report }\end{array}$ & & $\begin{array}{l}\text { ATP/OTP \& OTR } \\
\text { (Document \# TBD) }\end{array}$ & N.S. Cannon & Yes \\
\hline$\cdot$ & Safety Equipment List & & & & \\
\hline • & Environmental Impact Statement & & & & \\
\hline • & Environmental Report & & & & \\
\hline$\cdot$ & Environmental Permits & & & & \\
\hline • & Stress/Seismic Analysis & & . & & \\
\hline$\cdot$ & Stress/Design Report & & & & \\
\hline$\cdot$ & Equipment Specification & & & & \\
\hline • & Procurement Specification & & $\begin{array}{l}\text { Included in PR A31978 \& } \\
\text { A31980 }\end{array}$ & N. S. Camnon & Yes \\
\hline • & Construction Specification & & & & \\
\hline - & Essential Material Specification & & & & \\
\hline$\cdot$ & Technical Specification & & & . & \\
\hline - & As-built Drawing & & $\mathrm{TBD}$ & P. R. Deichelborer & Yes \\
\hline • & Interface Control Drawing & & & & \\
\hline • & Computer Software & & & & \\
\hline \multicolumn{6}{|c|}{ OPERATIONS: } \\
\hline & Operating and Maintenance Manuals & & & & \\
\hline & Operating Procedures & & TO-040-333* & D. A. Barnes & Yes \\
\hline • & Operation Instructions & & & & \\
\hline & Calibration Procedures & & TO-040-333* & D. A. Barnes & Yes \\
\hline
\end{tabular}




\begin{tabular}{|c|c|c|c|c|}
\hline 16. Documents or Other Items/Tasks to be Updated & \multirow{2}{*}{$\begin{array}{l}\text { 17. Funding } \\
\text { Source }\end{array}$} & \multirow[t]{2}{*}{ 18. Document Number } & \multirow{2}{*}{$\begin{array}{l}\text { 19. Responsibility } \\
\text { for Completion }\end{array}$} & \multirow{2}{*}{$\begin{array}{l}\text { 20. Required } \\
\text { prior to final } A B U \\
\text { (Yes/No) }\end{array}$} \\
\hline - Preventative Maintenance Procedures & & & & \\
\hline - Operations Safety Requirements & & & & \\
\hline \multicolumn{5}{|l|}{ QUALITY ASSURANCE: } \\
\hline - Inspection Plan & & TBD & R. R. True & Yes \\
\hline - $\quad$ QAPP & & & & \\
\hline - $\quad$ QAP JP & & & & \\
\hline - $\quad$ NEC Inspection & & & & \\
\hline \multicolumn{5}{|l|}{ PROCUREMENT ACTIVITIES: } \\
\hline - Vendor Information & & TBD & N. S. Cannon & Yes \\
\hline - Material List & & & & \\
\hline - $\quad$ Spare Parts & & & & \\
\hline - $\quad$ Purchase Requisition(s) & & PR A31978 \& A319830 & N. S. Cannon & Yes \\
\hline - $\quad$ ALARA Management Worksheet & & & & \\
\hline - Other Commercial Grade Item forms & & & & \\
\hline
\end{tabular}

* Minor changes (if any) are expected for the procedures. 


\section{PROJECTS: CHARACTERIZATION OPERATIONS AND ENGINEERING}

Cog/Field Engineer

\section{DA Barnes}

Cog/Field Engineer

Cog/Field Engineer

Cog/Field Mgr. NW Kirch

QA RR True

Safety LS Krogsrud

Environmental NA

Modification Projects

DS Tank Operations

Design Authority PF Kison

Design Engineer

Design Engineer

Design Engineer

Design Engineer

Design Engineer 
ATTACHMENT B: Neutron/Gamma Probe Schedule

HNF-3322 Rev. 0

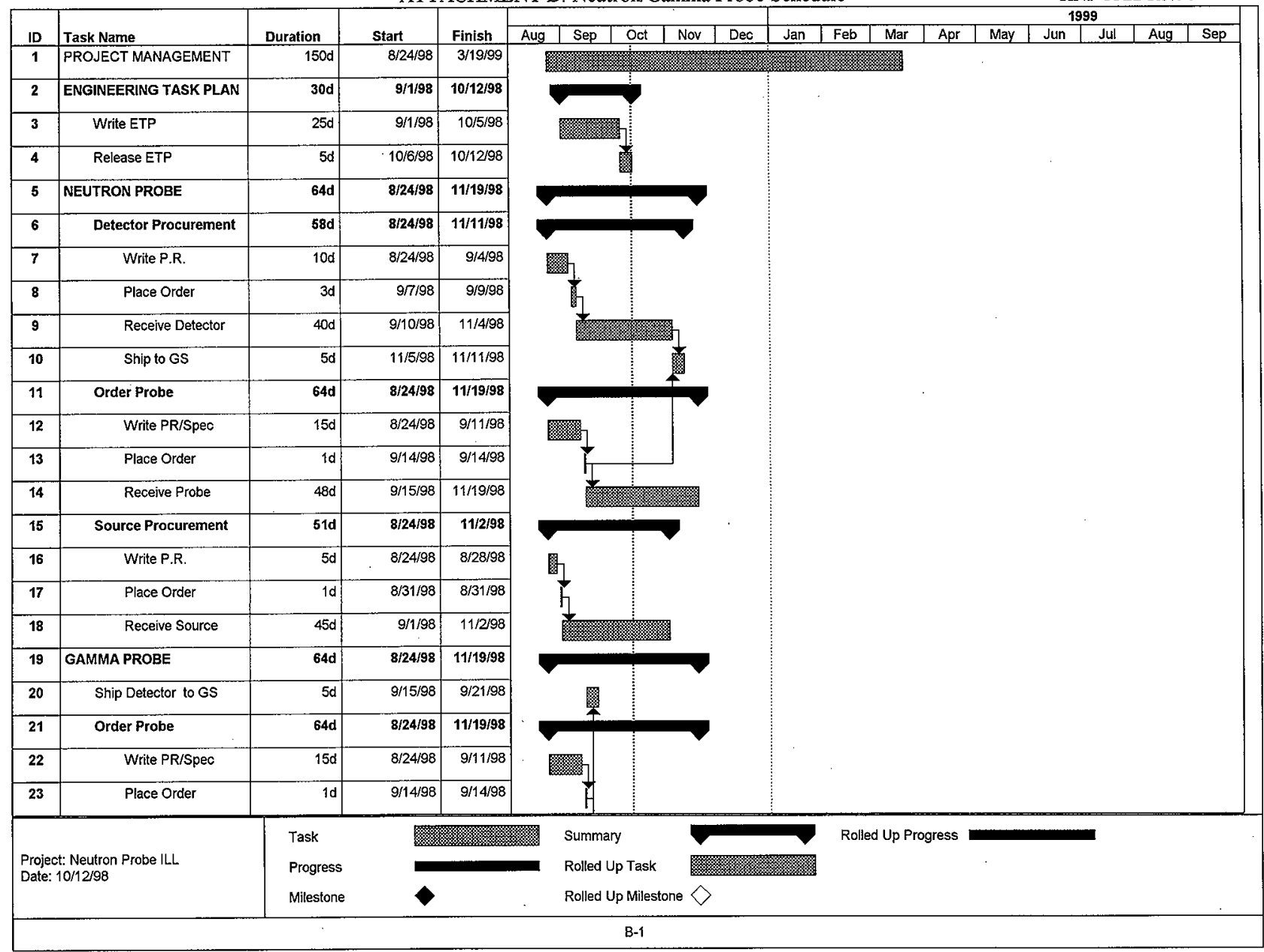


ATTACHMENT B: Neutron/Gamma Probe Schedule

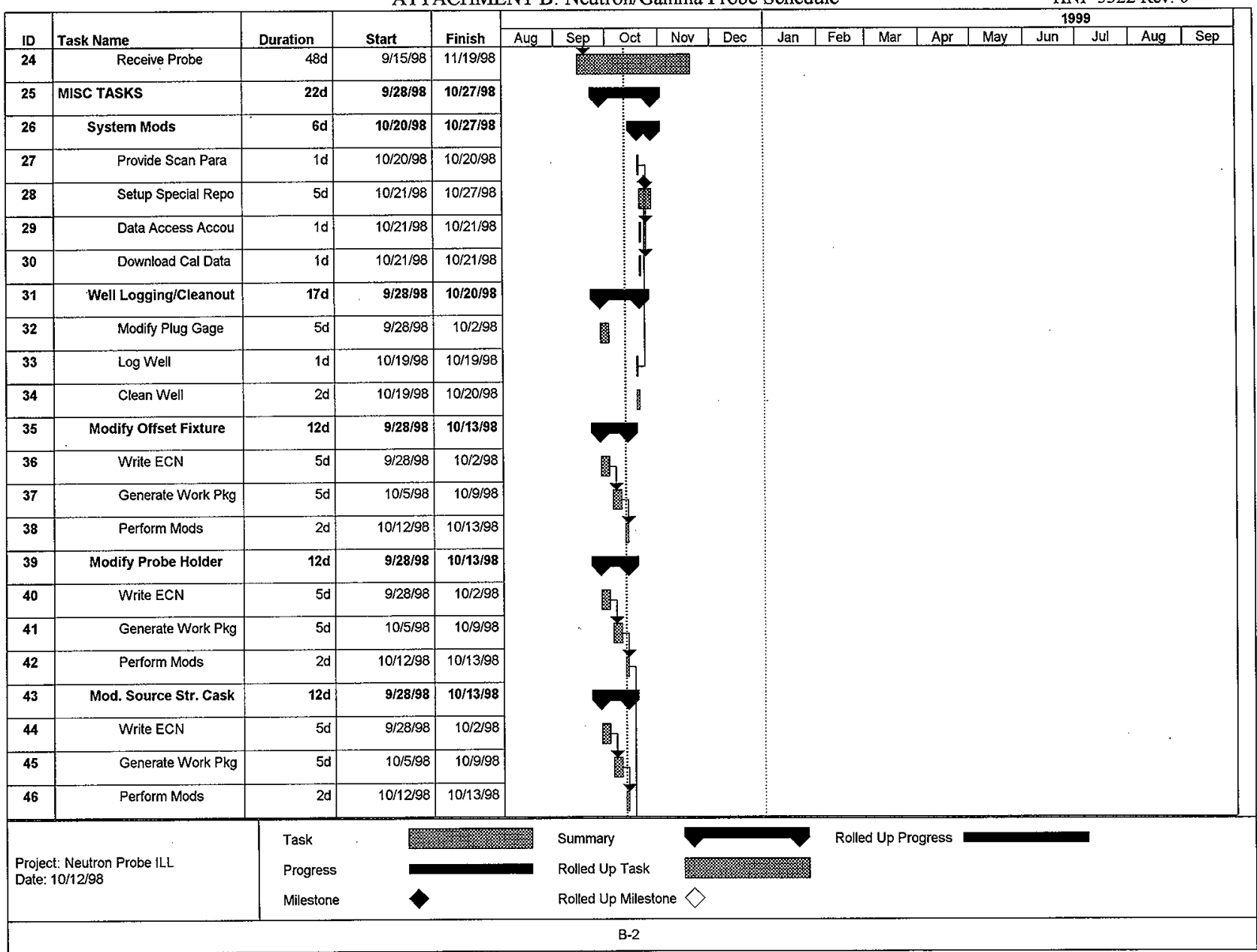


ATTACHMENT B: Neutron/Gamma Probe Schedule

HNF-3322 Rev. 0

\begin{tabular}{|c|c|c|c|c|c|c|c|c|c|c|c|c|c|c|c|c|}
\hline & & & & & & & & & & & \multicolumn{6}{|c|}{1999} \\
\hline ID & Task Name & Duration & Start & Finish & \begin{tabular}{l|l} 
Aug & Sep \\
\end{tabular} & Oct & Dec & Jan & Feb & Mar & Apr & May & Jun & Jul & Aug & Sep \\
\hline 47 & TESTING & 50d & 10/23/98 & 12/31/98 & & & & & & & & & & & & \\
\hline 48 & Pre-0p Testing & $20 \mathrm{~d}$ & 10/30/98 & $11 / 26 / 98$ & & & & & & & & & & & & \\
\hline 49 & Test Plan/Proc & $15 \mathrm{~d}$ & 10/30/98 & $11 / 19 / 98$ & & & & & & & & & & & & \\
\hline 50 & Cal fixture Data (2) & $5 d$ & $11 / 20 / 98$ & $11 / 26 / 98$ & & & & & & & & & & & & \\
\hline 51 & Mit/101A (2) & $5 \mathrm{~d}$ & $11 / 20 / 98$ & 11/26/98 & & & & & & & & & & & & \\
\hline 52 & ATP/OTP & $45 \mathrm{~d}$ & 10/23/98 & 12/24/98 & & & & & & & & & & & & \\
\hline 53 & Write ATP/OTP & $20 d$ & $10 / 23 / 98$ & $11 / 19 / 98$ & & & & & & & & & & & & \\
\hline 54 & Release ATP/OTP & $5 d$ & $11 / 20 / 98$ & $11 / 28 / 98$ & & & & & & & & & & & & \\
\hline 55 & Perform ATP/OTP & $10 \mathrm{~d}$ & $11 / 27 / 98$ & $12 / 10 / 98$ & & & & & & & & & & & & \\
\hline 56 & Evaluate Data & $5 d$ & $12 / 11 / 98$ & $12 / 17 / 98$ & & & & & & & & & & & & \\
\hline 57 & Release OTR & $5 d$ & $12 / 18 / 98$ & $12 / 24 / 98$ & & & & & & & & & & & & \\
\hline 58 & ABU & $5 \mathrm{~d}$ & 12/25/98 & $12 / 31 / 98$ & & & & & & & & & & & & \\
\hline 59 & Release ABU & $5 d$ & $12 / 25 / 98$ & $12 / 31 / 98$ & & & & & & & & & & & & \\
\hline 60 & POST-OP ANALYSIS/TEST & $15 \mathrm{~d}$ & $1 / 1 / 99$ & $1 / 21 / 99$ & & & & & & & & & & & & \\
\hline 61 & Implementation Plan & $15 \mathrm{~d}$ & $1 / 1 / 99$ & $1 / 21 / 99$ & & & & & & & & & & & & \\
\hline 62 & OPERATIONAL PHASE & $181 d$ & $1 / 22 / 99$ & $10 / 1 / 99$ & & & & & & & & & & & & \\
\hline 63 & ILL Measure. \& Anal. & $181 \mathrm{~d}$ & $1 / 22 / 99$ & $10 / 1 / 99$ & & & & & & & & & & & & \\
\hline
\end{tabular}

\begin{tabular}{|l|llll}
\hline & Task & Summary & Rolled Up Progress \\
\hline $\begin{array}{l}\text { Project: Neutron Probe ILL } \\
\text { Date: } 10 / 12 / 98\end{array}$ & Progress & Rolled Up Task \\
& Milestone & Rolled Up Milestone $\diamond$
\end{tabular}




\section{DISTRIBUTION SHEET}

\begin{tabular}{|c|c|c|c|c|c|}
\hline \multirow{2}{*}{$\begin{array}{l}\text { To } \\
\text { Distribution }\end{array}$} & \multirow{2}{*}{\multicolumn{3}{|c|}{$\begin{array}{l}\text { From } \\
\text { Electrical I \& C }\end{array}$}} & \multicolumn{2}{|l|}{ Page 1 of 1} \\
\hline & & & & \multicolumn{2}{|c|}{$\begin{array}{l}\text { Date 0ctober 12, } \\
1998\end{array}$} \\
\hline \multirow{2}{*}{\multicolumn{4}{|c|}{$\begin{array}{l}\text { Project Title/Work Order } \\
\text { Engineering Task Plan for Determining the Interstitial Liquid } \\
\text { Level in Tank 241-SY-101 Utilizing a Neutron Probe in the } \\
\text { Multifunction Instrument Tree }\end{array}$}} & \multicolumn{2}{|c|}{ EDT No. 140119} \\
\hline & & & & \multicolumn{2}{|l|}{ ECN No. NA } \\
\hline Name & MSIN & $\begin{array}{c}\text { Text } \\
\text { With All } \\
\text { Attach. }\end{array}$ & Text Only & $\begin{array}{l}\text { Attach./ } \\
\text { Appendix } \\
\text { Only }\end{array}$ & $\begin{array}{l}\text { EDT/ECN } \\
\text { Only }\end{array}$ \\
\hline $\begin{array}{l}\text { J. D. Adrian } \\
\text { D. A. Barnes } \\
\text { R. E. Bauer } \\
\text { N. S. Cannon (3) } \\
\text { J. D. Criddle, Jr. } \\
\text { P. R. Deichelbohrer } \\
\text { C. E. Hanson } \\
\text { G. D. Johnson } \\
\text { N. W. Kirch } \\
\text { P. F. Kison } \\
\text { L. S. Krogsrud } \\
\text { D. C. Larsen } \\
\text { D. Scott, Jr. } \\
\text { F. S. Stong } \\
\text { R. R. True } \\
\text { Central Files (1) + Orig. }\end{array}$ & $\begin{array}{l}\text { T4-01 } \\
\text { R2-11 } \\
\text { S7-73 } \\
\text { L6-38 } \\
\text { S7-12 } \\
\text { S7-12 } \\
\text { S7-12 } \\
\text { S7-73 } \\
\text { R2-11 } \\
\text { T4-07 } \\
\text { T4-07 } \\
\text { T4-08 } \\
\text { T4-01 } \\
\text { S7-12 } \\
\text { T4-07 } \\
\text { A3-88 }\end{array}$ & 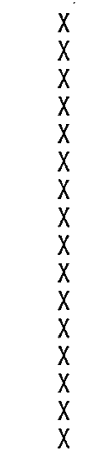 & & . & \\
\hline
\end{tabular}

